\title{
Walking, Talking, Performing in Place: Learning from/with/on the Land
}

\author{
Maya Tracy Borhani
}

\begin{abstract}
This autoethnographic essay describes an ambulatory workshop with fellow graduate students, a walking tour to remote parts of campus where we paused to consider writing prompts and to create short performative sketches highlighting the nature of our relationships to the land around us. In this reflection on our "walk and talk," I consider how teachers and students co-create what we learn together, the mysteries of engaging in interactive drama and poetry methods, and the performative ways in which we might come to know the places where we live and work more intimately and more imaginatively.

Too much thinking. Not enough loving. Too much writing. Not enough singing. And not enough art ... not enough dancing, either, and telling and retelling how the world got made and who made it and why. We love those who give us all these things because they remind us that everything is alive. And thinking. Not just us. Not just animals and plants. The energies, too, are alive. They are the mysterious ones that select pure water from the ocean and form clouds ... and bring it to our mountains so it can pour down in streams and rivers onto the plains and feed the plants and us. The world is alive and thinking and loving. These energies inspire us, they breathe into us not merely life, but meaning and art and love. If we listen. (Jim Watt, The Crow, February 2019)
\end{abstract}

What happens when we play upon the land, when learning arises directly from educational explorations in place? How can we encourage active witnessing and performative engagement with place, with the land we walk, work, and live upon? I am not an environmental educator, though I am passionate about taking students outside, off beaten tracks whenever possible, to hear, feel, sense, see, and breathe in the interrelated tonal, rhythmic, and visual symphony of earth, sun, sky, and sea. In my excursions on the land with elementary, secondary, and college-level students, we most often explore sensory impressions of the world around us, and inner contemplative spaces, through writing poetry, journal writing, and/or sketchbook drawing. There is no set assignment; rather, we take to the land to connect more deeply with everything around us, to draw inspiration from nature's palette, to reconnect with our own interiority, its unique voice, its innate wisdom. It's an experience with little direction, and no outward goal. The intent is connection with that place and with each other. Any writing that comes is a bonus. Our time spent dwelling outdoors is a way of being, of being-together-in-place (Larsen \& Johnson, 2017), of listening and responding to the land that sustains us in our various communities.

My current place of work and listening to the land lies on southern Vancouver Island, in British Columbia. Immersed in doctoral studies at the University of Victoria, my research focuses on intersections of poetic inquiry and pedagogy, drama in education, and lifelong learning with/from/on the land in the places we call home. Therein, I would like to gratefully acknowledge, with respect, the Lekwungen and SENĆOFEN 
speaking peoples on whose traditional territory the university stands and where I am grateful to visit and work, as well as the Songhees, Esquimalt, and WSÁNEĆ peoples whose historical relationships with the land continue here to this day.

This essay describes a participatory workshop I led as part of a 2019 Association of Graduate Education Students (AGES) conference at the University of Victoria, themed Weaving Connections: Collaboration and Mentoring. The "walk and talk" workshop was designed to connect participants (mostly graduate education students) with the land where we study, work, and play, and to explore performative practices there on the land, under cloud and sky, in hopes of generating new ways of seeing, being, attending, and experiencing ourselves in place.

I was interested in exploring simple performative methods in poetry and drama with my fellow graduate students (immersed in the mostly cerebral nature of their studies, as so many of us are), and the critical intersections of curriculum theory, eco-pedagogies, and poetic/performative inquiry as pedagogy and research methodology. I was curious if the students would give in to the simple "feeling" exercises I would offer, if shyness or self-consciousness would overwhelm some people, or if an inability to connect with the land (and its ceaseless performance amongst/with us) would paralyze the group. Furthermore, I was excited to play with Tim Ingold and Lee Vergunst's (2008) description of walking as a kind of "bodily performance" with a group of adult learners: "[W]alking comprises a suite of bodily performances that include observing, monitoring, remembering, listening, touching, crouching and climbing. And it is through these performances, along the way, that . . knowledge is forged" (p. 5).

Before our walk, I asked the group to consider their impressions of "the narrative nature of our worlds" (personal communication, Margaret McKeon, March 27, 2018); what might that mean, and what might such a "narrative" look like, smell, taste, or sound like? This idea of narratives of/on the land—-the earthand by extension, our lives lived upon the land-is, for me, an ontological commitment and epistemological imperative, expanding the idea of "story" beyond that of the merely human, into otherthan/more-than-human worlds, including that of the land itself. My own inquiries into such topics arise from the roots of my settler-immigrant descended presence here (a visitor to British Columbia, and a lifelong resident of Northern California) as well as from living in places within a (neo)colonial context that are yet experiencing (re)colonization while simultaneously working to decolonize hearts/minds/actions. As McKeon reminds us (personal communication, March 27, 2018), much has been written by Indigenous scholars and from decolonizing perspectives on the subject of our relationships to land, while less work has been undertaken by non-Indigenous scholars on this subject. My own interest in this topic arises from inspiration, and further questing, around ideas of relation and relationality, responsibility, and rematriation.

Furthermore, I have a passionate interest in cross-curricular/cross-fertilizing intersections between Western epistemological thought and Indigenous ways-of-knowing, between literary and oral cultures, between mythopoetics and deep ecology, between body/mind, heart/brain, and my own deeply rooted connection with and to the earth. The "walk-and-talk" method I undertook for this workshop is modeled on the idea of a walking methodology (Ingold \& Vergunst, 2008), and the idea of paying close attention 
as we go: a pedagogy of listening to, and learning from and with, the land (Chambers, 2008). When we listen to the land, we begin to approach, respectfully, the "wisdom that sits in places" (Basso, 1996), and to develop critical awareness (eyes, ears, senses, intuition) for other ways of knowing and being.

Why does any of this matter? How do such concerns intersect with the panoply of daily life, mundane concerns that overcrowd our hearts and minds, pressing demands that leave little time for contemplative walking and performative explorations on the land? What insights come while walking? What is the pedagogy of paying close attention? What can we learn from listening to the land? Can these insights be applied wherever we travel on this great earth, fostering an expanded praxis of stewardship and sustainable practices, ethos of care, conservation, and consciousness for all-ways-of-knowing? It's my firm belief that, indeed, these insights can be extended outward into an over-arching ethos of care for the places we live_-all over the globe_-and thereby become a "lived curriculum" (Aoki, 1993) that can be shared, taught, and experienced by all. Practicing critical (creative) eco-pedagogical engagement such as this flows alongside, is akin to, the art of "living inquiry" (Meyer, 2010), or attunement to natural and material elements of the world around and within us. We attend to where we are, what is happening around and inside of us, how we feel, what we observe and sense. In attending, we attune. The minutiae are everything in this practice.

The day of the workshop dawned clear and sunny, a crisp spring day-perfect walking weather! We gathered in a large meeting room in the Student Union building, a surprisingly large group of 15 participants. We had only one hour for our walk, including three stops I had in mind, where we would explore place through performative and poetic methods. I had the walk-and stops-timed to a tee. I explained to everyone beforehand what our general game plan would be: we would stop to meditate, write, and to consider performatively some ways in which we might come to know the places where we work and play more intimately. I shared the quote from Ingold and Vergunst about walking as bodily performance, hoping to encourage and inspire such a sense of engaged performativity in our walk.

I asked the group, many of whom knew each other from their shared course work in the M.A. and Ph.D. programs, if they would please try to walk silently, attending to the landscape as we moved through it: I explained that this was integral to successful completion of the activities we would undertake later, as we would draw on observations and sensory impressions forged along the way. I encouraged them to listen and attend to minutiae, to the unseen; to look up, down, all around. I encouraged them to walk off the pavement as much as possible (and in fact, I led them in such ways, which I could tell confounded some); most of all, I strongly encouraged them not to talk to one another, but to walk in silence, observing and attending; listening, smelling, tasting cherry blossoms on the breeze, the bite of early spring air on the tips of noses, the distant call of a seagull, or crow's strident cry.

As it turns out, my group of adult learners must have needed a different experience on their sojourn: instructions to walk in silence flew straight away on the first wisp of breeze to greet us as we stepped into the warm sunlight. I tried, once or twice, to encourage the requested silence, and the meditative attention it would encourage; but as experienced teachers know so well, sometimes it's better to go with the flow 
than to try and change the way things are, and such seemed to be the case with my happy (but chatty) group of graduate students.

Once I realized silence was not going to be the order of this burgeoning spring day, I reiterated aloud my hope that we might deepen our relationships to/with the land around us by focusing on our senses beyond that of sight alone, tuning into sound, smell, taste, and even touch, encouraging the students to interact with the landscape surrounding them as we walked. I was struck by how my group of student-walkers were dwelling more in talk than in meditative silence. Perhaps this was a sign that, as graduate students, we need more opportunities to converse and share with one another, including more such opportunities outside, and while walking and talking together. These are practices and ideas - praxis - that make sense to me: could it be that everyone feels a need for a practice such as this, a walking methodology with keen attention to the world around us that such activity affords?

In keeping with the change of lesson plan dictated by the group's tone and demeanor, I also changed gears, skipping our first "planned" stop: a short break in which to practice silent observation of the world around us. I'd hoped to have everyone close their eyes and listen to the sounds around them, to really feel beneath the soles of their feet, noting how the earth holds them up; what did they feel on their skin, and what did the sun warming their eyelids from within look like?

Onwards. Today's would be a more verbal observation of that world!

I picked up my pace and hustled them along to a spot far on the edge of campus, where the grass grows unmown, and the hillside slopes downward overlooking the glittering blue sea far below. There, under the sprawling branches of a newly leafed-out Big-Leaf Maple tree, we stopped, and finally, everyone was silent, catching their breath. I grabbed my moment to share with them the first exercise we would do in our performative exploration on/with the land.

We launched straight into our poetry-writing exercise. I'd brought along paper and pencils for all, and once everyone had gathered round, I read them a short poem by American poet and war-resistor William Stafford (1992):

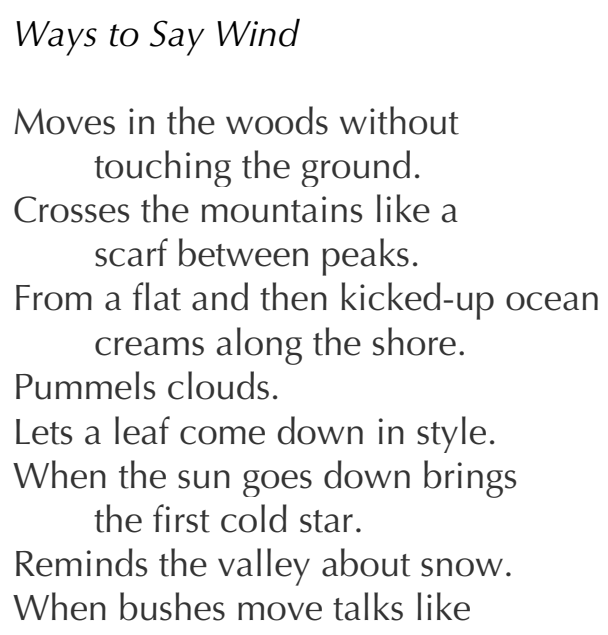


a rabbit.

Lost all night, calls for

friends-help-justice.

Remembers the dead.

At first, the assembled crowd is puzzled. I wonder if these metaphors, Stafford's excellent and sublime use of only action verbs to describe the many "ways to say wind," are "lost in translation" for the group of mostly nonnative English speakers. I, who have grown up immersed in the English poetic idiom, experience salvation with Stafford's imaginative comparatives, the voices he attributes to wind, and the creatures who hear when wind speaks. But are these images, in English, too metaphoric for newer speakers to properly comprehend? I am not an ESL instructor, so this moment in our workshop caught me off guard. Or, I wondered next—as is often the case even in native English-speaking classrooms-is it that I'm speaking poetically that is intimidating? This is a question for further study, suggesting ways in which we might use poetry, specifically, in ESL instruction, as well to the efficacy of promoting more poetic pedagogy in general.

However, as a poetry instructor, and despite such initial intimidations, I've never seen poetry not speak to its intended audience, in the end. One way or another. So, with that truism in mind, we pushed on into the "assignment." Normally—with grade school students—l ask them to make up their own version of Ways to Say Wind. I tell them they can pick anything they want to give voice to, with the only limitation being that it must be something in the natural world: wind, water, sky, sun, turtle, eagle, meteor, thunder. There is no fixed requirement as to the poem's length; the only "rule" is that, like Stafford, they must use only active verbs. No form of the verb "to be" is allowed. (Many balk at this instruction, at first! Then, their world opens up to them, with realization of the wealth of activity to be found in almost any other verb!) The natural element or creature they choose to describe must find active ways to move, think, speak, and exist: pummel, move, call, remind, remember, as Stafford intones. These verbs are evocative, and in their very stance of creating some sort of action, they are performative. This is one way to teach performative writing to our students. And I don't think William Stafford would mind that we are practicing this revered poetic pedagogy, known as "mirroring" or shadowing, with his fine poem.

This group of adult students, however, has other ideas about "ways to say" many things. I fear we've lost some of our inward-looking vocabulary through not having taken a quiet, meditative walk to our sheltering maple tree. Some students seem confused; instead of working individually, as instructed, they clump together in small groups, and nervously huddle over their pieces of paper. Moving among the groups, and sensing some discomfort with the assignment, I change the instructions: working together, I suggest, see if you can come up with the thing you want to describe (sunlight, wind, maple tree), and work together to find active ways to describe that object, to say its name. This suits them better, as a great sigh seems to escape the entire group. Our short time on this jaunt is ticking, and I hate to rush poetry, ever. But, after about five minutes, with incremental warnings in between, I stop them and ask if anyone would like to read some of their poem(s).

No volunteers. At first. Shyness, before finding one's voice, before performativity swells, before words for ... water. A young man volunteers, and describes water flowing nearby —we can hear it, but not see 
it from where we stand-the sound is like music, he incants. Good imagery, I encourage. Someone else describes the sun drenching our faces-good verb, I exclaim, well pleased with the creative use of an action verb. I share a line, to encourage others, and to remind us all that this is not an exercise in perfection, but rather in practicing acute attentiveness and in exploring language. Ways to say maple leaf: floats to earth in a slow sashay. A few more people volunteer their one-liners, which seem to be the norm, rather than whole poems built on an idea of scaffolding images. And that's fine. We didn't have much time to work on our poems, nor for me to provide individual assistance (as I would normally do in a smaller classroom setting). Still, the idea is to nurture comfort in thinking poetically, in seeing our world in these more performative ways: how do everyday elements, forces, things, act, do, and perform in the world and on us? When we play with our verbiage, we capture more accurately this delicate passion play of the world around (and inside of) us.

Next, it's time to move along in our walk, but we don't go far this time: just over to a large meadow to the east of our maple tree, with room to spread out and flat ground to steady our movements. By now, I'm teaching on my feet, the intended lesson plan long ago out some imaginary window in the vast, blue sky. I really want to play with the more experimental part of our brief time together-drama exercises. I'm used to teaching poetry, whether it goes "well" or language is stiff and stuttering; this is my first time leading a drama exercise on my own.

We were nearly out of time, time that was taken up encouraging the group to share their poetic insights. Yet, that was an important use of our time, important for the group to hear and revel in their own creations, and the knowledge that there is no right answer in poetry; all of their images had value and meaning. What happened next exceeded any hoped-for expectations, and (re)confirmed the value of playing performatively in all our educational endeavors.

I gathered everyone into a tight circle and explained the next step of our "walk and talk" excursion. The original intent of our final activity was to create three-part tableaux depicting lines from three different students' poems, moving between the three different "images" in a series of still-life compositions. Tableaux, "a key strategy in drama education . . . also known as still pictures, freeze frames, depictions, statues or sculptures, involve the dramatic elements of silence and stillness" (Prendergast \& Saxton, 2013, p. 110), qualities I thought would blend well with the (intended) meditative nature of our walk, and images gleaned from that stillness and silence through the students' poetic lines. Tableaux work is very accessible and "safe ... for generally unskilled participants" (p. 110), such as this group of non-drama students, although participants are typically advised they will have to hold a pose for a while, and so, accordingly, to be careful not to overly exert themselves in the postures they choose.

I asked the group to gather into threesomes, and explained the basic premise of tableaux: create a still image with their bodies to represent an idea, or an image, from their poems. In the interests of our waning time in the field, I offered them the original option to make up to three images (one from each of their poems), or to simply make one image together that they would hold for the group to view, while one of them recited the poetic line it expressed. 
The importance of creating these simple tableaux cannot be overstated. At the root of performance is play (not a stage-play, but sheer child-like play, play for fun); without play in our educational processes, we let go the magic, the spark, the imagination. Citing Donna Haraway (2016, p. 56), Flynn and Reed (2019) note that, "Play is integral for reveling in embodied, more-than-cognitive ways of knowing and cultivating ecological imagination through 'attentive practices of thought, love, rage and care'" (pp. 134-135). All these emotions became embodied through the students' tableaux. (Unfortunately, I did not keep copies of the students' poetic lines, preferring to let them keep these for themselves; in the midst of our brief walk, there was no time to transcribe the lines into my own notebook. As much as possible, I have tried to describe the imagery of the lines, as expressed through tableaux.)

The first group chose to enact the original idea for the exercise, flowing beautifully between three separately composed lines of poetry (recited as they struck each pose): the sun shone like an orange fire; then a bird sang in flight; finally, spring grass sprouted in the field. The threesome stood with arms flung wide and outstretched, distinct flames reaching skyward, then shifted to wings of a bird in flight (one body in front, arms flung wide) with tail flowing behind (two bodies laid out on the ground behind her), before finally shifting to three crouched sprouts with hands waving above their heads. I was astounded at the astute interpretation of their poetic lines in tableaux. The group at large was delighted, as well. Others chose to interpret one line of poetry in their three-way tableaux: a star shooting through the sky; that distant waterfall we'd heard earlier (three sets of bodies, arms, legs, all flowing downward in the ripple of that liquidity); another bird, this one too close to the sun, three sets of arms echoing wings in flight, in varying stages of melt. As Augusto Boal says, quoted in Prendergast and Saxton (2013):

Image is a language. All images also are surfaces, and, as such, they reflect what is projected on it. As objects reflect the light that strikes them, so images in an organized ensemble reflect the emotions of the observer, her ideas, memories, imagination, desires... (Boal, 1992/2002, p. 175)

Through their ability to take in this simple creative drama exercise and produce stunning, descriptive tableaux, I believe these graduate students came to understand the value of performative ways of learning and experiencing the world around them-cross-curricular ways outside of their respective fields of study, yet nonetheless useful, valuable even, for the expansion of their own pedagogic and epistemic hearts and minds. Walking, talking, breathing, and learning with and from the land all around us, we learned and practiced new (old) ways of noticing and attending; what ethnographer Tim Ingold (2000) calls a "sophisticated perceptual awareness," which in turn supported us in cultivating "a direct and sensuous engagement with the world" (Chambers, 2008, p. 121), as evidenced through the students' poetic lines, and their eager engagement with creating dramatic tableaux.

When did our walk begin? When will it ever end? . . Life itself is as much a long walk as it is a long conversation, and the ways along which we walk are those along which we live. . . walking is a profoundly social activity: . . . in their timings, rhythms, and inflections, the feet respond as much as does the voice to the presence and activity of others. Social relations . . . are not enacted in situ but are paced out along the ground. (Ingold \& Vergunst, 2008, p. 1)

I am coming to understand these acts in my own life, as an educational researcher, as both walking and dwelling methodology, where my creative "research . . . is embodied and performative; it requires us to 
walk and dwell ... [it] entails more than conventional participant observation . . . rather an attunement to the embodied landscape as a primary way of coming to know ourselves in relation to others" (Johnson \& Larsen, 2013, p. 15), and in direct relation to those very places where we dwell. We come into being, into ecological imagination, into performative educational practices, when we understand that all living/teaching/learning is performative, and that our place on earth innately embodies each of our own performances there. In slowing down and choosing to take more (frequent) meditative or social walks in nature, in the company of others, in playful reverie in the world that is our home, we tune into the kinds of active verbiage-and living - that William Stafford models so well. We come into our teaching in performative ways, in language and in action. In our writing, and in enactments of our pedagogy, with our students in the field, and in our own scholarly processes, we contemplate and embody performances of place.

In every performance, the three elements of place, the play, and the people (actors and audience) interrelate and illuminate one another in moving and provocative ways. Time allows these elements to coexist and converse, creating an experience that engages imagination and emotion in an intensified inhabiting of place. Unifying artistic, ecological, and historical sensitivity to a specific locale, [this] project fosters a richly embodied, lived experience of landscape . . . this heightened experience can lead to a new awareness of the natural environment and of our ethical responsibility to it. (Popov, 2019, p. 82)

This is one way to make room in our busy lives for deep (if momentary) engagement with the land where we live, work, and visit: On walks to work, on the bus while looking out the window, while noticing little things on the sidewalk, in the branches of the trees, above our heads in clouds rolling by, we're practicing close attention, and coming into literacy with the land. Take time for poetry (it's so personally and politically regenerative, as well as performatively enriching), and for playing: with drama, with each

other, in a forested field where many other-than-humans will see, hear, witness, and be a part of this unfolding play of life on a turning blue-green marble, orbiting a faraway sun.

\section{References}

Aoki, T. (1993). Legitimating lived curriculum: Towards a curricular landscape of multiplicity. Journal of Curriculum and Supervision, 8(3), 255-268. Retrieved from https://pdfs.semanticscholar.org/09c0/8e959a4a83c9716e4bafdf233639a8a4c070.pdf

Basso, K. (1996). Wisdom sits in places. University of New Mexico Press.

Boal, A. (1992/2002). Games for actors and non-actors (2nd ed.). (A. Jackson, Trans.) Routledge.

Chambers, C. (2008). Where are we? Finding common ground in a curriculum of place. Journal for Canadian Association of Curriculum Studies, 6(2), 113-128.

Flynn, A., \& Reed, A. (2019). Building ecological ontologies: EcoJustice education becoming with(in) art-science activism. In R. Foster, J. Makela, \& R. A. Martusewicz (Eds.), Art, ecojustice, and education: Intersecting theories and practices (pp. 124-140). Routledge.

Haraway, D. (2016). Staying with the trouble: Making kin in the chthulucene. Duke University Press. 
Ingold, T., \& Vergunst, J. L. (2008). Introduction. In T. Ingold \& J. L. Vergunst (Eds.), Ways of walking: Ethnography and practice on foot (pp. 1-19). Ashgate Publishing Limited.

Johnson, J. T., \& Larsen, S. C. (2013). Introduction: A deeper sense of place. In J. T. Johnson \& S. C. Larsen (Eds.), A deeper sense of place: Stories and journey of collaboration in Indigenous research (pp. 7-17). Oregon State University Press.

Larsen, S. C., \& Johnson, J. T. (2017). Introduction. In S. C. Larsen \& J. T. Johnson (Eds.), Being together in place: Indigenous coexistence in a more than human world (pp. 1-22). University of Minnesota Press.

Meyer, K. (2010). Living inquiry: Me, myself, and other. Journal of Curriculum Theorizing, 26(1), 85-96. Retrieved from https://journal.jctonline.org/index.php/jct/article/view/150/64

Popov, B. (2019). The Uncle Vanya project: Performance, landscape, and time. In R. Foster, J. Makela, \& R. A. Martusewicz (Eds.), Art, ecojustice, and education: Intersecting theories and practices (pp. 82-94).

Prendergast, M., \& Saxton, J. (2013). Applied drama: A facilitator's handbook for working in community. Intellect.

Stafford, W. (1992). Ways to say wind. In My name is William Tell. Confluence Press.

Watt, J. (2019). The Crow (private journal). The Crow.

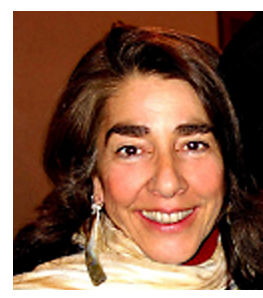

Maya Tracy Borhani is a doctoral candidate in Curriculum \& Instruction at the University of Victoria, British Columbia, engaged in autoethnographic research into what it means to live poetically in times of precarity, in service to poetry, dedicated to the life of the heart. When not on Vancouver Island preparing for comprehensive exams, Maya revels in returning home to the mountains of northern California, walking in alpine forests and lush meadows alongside crisply flowing rivers and serene lakes that restore her and inform the work that lies ahead. 
